\title{
Leucocyte sodium pump activity after meals or insulin in normal and obese subjects: Cause for increased energetic efficiency in obesity?
}

\author{
LEONG L NG, MORAG A BRUCE, T DEREK R HOCKADAY
}

\begin{abstract}
As cellular sodium pumping is an energy consuming process and differences in the obese may account for their energetic efficiency, leucocyte sodium-22 efflux was studied in obese and normal volunteers both in the fasting state and after a test meal or infusion of glucose and insulin intravenously. The ${ }^{22} \mathrm{Na}$ ouabain sensitive efflux rate constant was significantly higher in obese subjects than normal (mean (1 SD) $2.69(0.40) / \mathrm{h} v 2.35(0.49) / \mathrm{h})$. Two hours after a $4.2 \mathrm{MJ}(1000 \mathrm{kcal})$ meal there was an increase in the efflux rate constant from its fasting value in normal weight subjects $(2.39(0.33) / \mathrm{h}$ to $2.71(0.40) / \mathrm{h})$ but not in obese subjects $(2.65(0.54) / h$ to $2.61(0.58) / h)$. The rise in ouabain sensitive efflux rates was significantly higher in normal than obese subjects. Both groups showed a rise in intracellular sodium concentrations. The euglycaemic clamp produced similar results.

Feeding or infusion of insulin increases sodium pump activity more in normal than obese subjects. This difference may contribute to any defective dietary thermogenesis in obesity, which may lead to energetic efficiency and a tendency to gain weight.
\end{abstract}

\section{Introduction}

In eukaryotic cells the maintenance of sodium and potassium concentrations against their electrochemical gradients entails the active transport of these ions by the sodium pump. $\mathrm{Ob} / \mathrm{Ob}$ mice have reduced sodium pump activity in liver and muscle compared with their lean counterparts, ${ }^{1.3}$ and a reduction in this portion of energy expenditure may account for the positive energy balance of $\mathrm{Ob} / \mathrm{Ob}$ mice. Sodium pump activity has been estimated to contribute up to $40 \%$ of energy expenditure at rest in man..$^{4-6}$ Energy

Sheikh Rashid Diabetes Unit, Radcliffe Infirmary, Oxford OX2 6HE LEONG L NG, MA, MRCP, MRC training fellow MORAG A BRUCE, PHD, research fellow

T DEREK R HOCKADAY, DPHIL, FRCP, consultant physician

Correspondence to: $\mathrm{Dr} \mathrm{Ng}$. expenditure at rest may account for up to $40 \%$ of man's total daily energy expenditure, ${ }^{7}$ the other contributory factors being the thermic effects of food and exercise. A defect in dietary thermogenesis has been reported in obesity, ${ }^{8-11}$ and obese people may also show a reduced thermic response to a glucose and insulin infusion ${ }^{12}$ that possibly is associated with their insulin resistance.

The purpose of this study was to examine leucocyte sodium pump activity in man. Initial reports of reduced sodium pump activity in erythrocytes from obese subjects compared with normal ${ }^{13-15}$ were not confirmed by later work. ${ }^{16}{ }^{17}$ The nucleated leucocyte should be more representative of other cells in the body. Leucocyte sodium pump activity was examined in normal weight and obese volunteers at rest, after feeding, and in response to an intravenous glucose and insulin infusion.

\section{Materials, subjects, and methods}

All chemicals were Analar. Sodium-22 was from Amersham International, TC 199 (tissue culture fluid) from Wellcome Diagnostics, and ouabain from the Sigma Chemical Co.

\section{SUBJECTS}

Fifty volunteers of normal weight ( 22 men, 28 women; mean age 32.9 (SD 11.4 ) years; mean body mass index (weight $(\mathrm{kg}) /$ height $(\mathrm{m})$ squared) 21.9 (SD 1.9)) and 24 obese subjects (eight men, 16 women; mean age $43.9(11.9)$ years; mean body mass index $34.0(6.5)$ ) were recruited in answer to an advertisement. All were normotensive, and none had any known metabolic, endocrine, or electrolyte disorder. In particular, all subjects were euthyroid. Premenopausal women were studied in the follicular phase. No subject was receiving any drugs, including oral contraceptives. In all cases weight had been stable for at least six months before the study, and none of the obese subjects was taking a weight reducing diet. A dietary survey in 11 normal and 14 obese subjects showed comparable dietary carbohydrate intakes of 225 (SD 66) and 245 (70) g/day, respectively, which were maintained up to the study days. Blood pressure was measured in the right arm in supine subjects after 30 minutes' bed rest using a Hawksley random zero sphygmomanometer by one operator and the average of three readings taken. All subjects gave informed consent and the study was approved by the Oxfordshire ethical committee. 


\section{BLOOD SAMPLES}

Subjects were studied after a 12 hour overnight fast and $60 \mathrm{ml}$ blood taken after 30 minutes' bed rest for plasma insulin, glucose, urea, and electrolyte determinations and leucocyte electrolyte and ${ }^{22} \mathrm{Na}$ efflux studies.

\section{TEST MEAL}

Thirteen obese subjects (five men, eight women; mean age $42.9(13 \cdot 3)$ years; mean body mass index $32.0(3.9)$ ) and 11 normal weight subjects (four men, seven women; mean age $45 \cdot 5(13 \cdot 9)$ years; body mass index $22 \cdot 1(1 \cdot 6)$ ) were given a test meal of $4.2 \mathrm{MJ}(1000 \mathrm{kcal})$ composed of $15 \%$ protein, $30 \%$ fat, and $55 \%$ carbohydrate. Subjects fasted overnight for 12 hours. A venous cannula was inserted in the antecubital fossa on arrival at the laboratory. After an hour's bed rest four fasting blood samples were taken for insulin, glucose, and non-esterified fatty acid determinations. The meal was consumed within 15 minutes later and blood samples taken at half hour intervals thereafter for two and a half hours. A $40 \mathrm{ml}$ blood sample was taken immediately before and two hours after the meal for leucocyte ${ }^{22} \mathrm{Na}$ efflux and intracellular electrolyte studies. being spun down every four minutes for 20 minutes. The radioactivity from the cell pellets was counted on a gammacounter till more than 10000 counts above background were recorded. The total and ouabain insensitive efflux rate constants were determined by linear regression of $\log _{e}$ cellular radioactivity against time. The ouabain sensitive efflux rate constant is the difference between the two and represents sodium pump activity. ${ }^{21}$ The coefficients of variation (by the method of duplicates, where coefficient of variation $=(\text { sum } \text { of squared differences } / 2 \mathrm{n})^{0.5} /$ mean) for 13 subjects on two $\mathbb{D}$ different days one week apart were $13.3 \%$ (ouabain insensitive efflux rate constant) and $7 \%$ (ouabain sensitive efflux rate constant). There is no $?$ difference in ouabain sensitive efflux rate constants between polymorphonuclear and mononuclear leucocytes. ${ }^{22}$

\section{Intracellular electrolytes}

The other half of the isolated leucocyte pellet was resuspended in TC 199 and kept at $37^{\circ} \mathrm{C}$ for half an hour. The cells were then spun down and washed thrice with ice cold isotonic magnesium chloride buffer $\left(\mathrm{MgCl}_{2} 95 \mathrm{mmol} / \mathrm{l}\right.$, trometamol (TRIS) base $5 \mathrm{mmol} / \mathrm{l}$, made up in Analar water, $\mathrm{pH} 7 \cdot 4$ with $\mathrm{HCl})$. This washing does not lead to substantial loss of intracellular sodium

Body mass index, fasting plasma insulin concentrations, and leucocyte parameters in normal weight and obese subjects. Values are means (SD in parentheses)

\begin{tabular}{|c|c|c|c|c|c|c|}
\hline & \multicolumn{3}{|c|}{ Normal weight group } & \multicolumn{3}{|c|}{ Obese group } \\
\hline & $\operatorname{Men}(n=22)$ & Women $(n=28)$ & All $(n=50)$ & $\operatorname{Men}(n=8)$ & Women $(n=16)$ & All $(n=24)$ \\
\hline $\begin{array}{l}\text { Body mass index }\left(\mathrm{kg} / \mathrm{m}^{2}\right) \\
\text { Fasting insulin (mU/) } \\
\text { Leucocyte parameters: }\end{array}$ & $\begin{aligned} 22.7 & (1 \cdot 6) \\
7.8 & (3 \cdot 1)\end{aligned}$ & $\begin{aligned} 21.4 & (1.9) \\
3.2 & (3.7)\end{aligned}$ & $\begin{array}{r}21.9(1.9) \\
7.4(3.4)\end{array}$ & $\begin{array}{l}32.9(5 \cdot 5)^{\star \star \star \star} \\
24.6(17 \cdot 9)^{\star}\end{array}$ & $\begin{array}{l}34 \cdot 5(7 \cdot 1)^{\star \star \star \star} \\
15 \cdot 6(8 \cdot 9)^{\star \star \star \star}\end{array}$ & $\begin{array}{l}34 \cdot 0(6 \cdot 5)^{\star \star \star \star} \\
18.6(13 \cdot 9)^{\star \star \star \star}\end{array}$ \\
\hline $\begin{array}{l}\text { Intracellular sodium (mmol/kg) } \\
\text { Ouabain sensitive efflux rate constant }(/ \mathrm{h}) \\
\text { Ouabain sensitive efflux rate }(\mathrm{mmol} / \mathrm{kg} / \mathrm{h})\end{array}$ & $\begin{array}{l}22 \cdot 1(5 \cdot 4) \\
2 \cdot 42(0 \cdot 5) \\
55 \cdot 4(17 \cdot 5)\end{array}$ & $\begin{array}{l}33.6(9 \cdot 4) \mathrm{ttH} \\
2 \cdot 29(0 \cdot 49) \\
82.8(27 \cdot 5) \mathrm{tt}\end{array}$ & $\begin{array}{l}27 \cdot 9(9 \cdot 5) \\
2 \cdot 35(0 \cdot 49) \\
69 \cdot 1(26 \cdot 6)\end{array}$ & $\begin{array}{l}22 \cdot 5(5 \cdot 6) \\
2 \cdot 61(0 \cdot 3)^{\star} \\
68 \cdot 6(27 \cdot 1)\end{array}$ & $\begin{array}{l}28.9(6 \cdot 2) \dagger \\
2 \cdot 84(0 \cdot 54)^{\star \star} \\
75 \cdot 1(18 \cdot 9)\end{array}$ & $\begin{array}{l}26 \cdot 5(6 \cdot 6) \\
2 \cdot 69(0 \cdot 4)^{\star \star \star} \\
72 \cdot 7(21 \cdot 7)\end{array}$ \\
\hline
\end{tabular}

Obese $v$ normal weight subjects: ${ }^{\star} \mathrm{p}<0.05,{ }^{\star \star} \mathrm{p}<0.01,{ }^{\star \star \star} \mathrm{p}<0.005,{ }^{\star \star \star \star} \mathrm{p}<0.001$.

Women $v$ men: $\mathrm{tp}<0.05, \mathrm{ttp}<0.01, \mathrm{ttp}<0.005, \mathrm{H}+\mathrm{tp}<0.001$

\section{HYPERINSULINAEMIC-EUGLYCAEMIC CLAMP}

Eleven obese subjects (five men, six women; mean age $42 \cdot 3(13 \cdot 1)$ years; mean body mass index $31 \cdot 2(2 \cdot 7)$ ) and 10 normal weight subjects (five men, five women; mean age $43 \cdot 2(16 \cdot 7)$ years; mean body mass index $22 \cdot 3(2 \cdot 1)$ ) were studied by the euglycaemic clamp technique. All the obese subjects and six of the normal subjects had also been given the test meal.

The method was based on the minimal model of Bergman et al. ${ }^{18}$ Volunteers reported to the laboratory after an overnight fast and had two venous cannulas inserted, one in each arm, for blood sampling and for the infusion of insulin and $20 \%$ dextrose. The distal arm vein used for blood sampling was kept warm by a fan heater. After one hour's rest fasting blood samples were taken for plasma insulin, glucose, non-esterified fatty acid, and leucocyte studies. A primed continuous infusion of human insulin (Eli Lilly) was then started at a rate of $40 \mathrm{mU} / \mathrm{m}^{2}$ body surface area/min and blood samples taken every five minutes for glucose measurement on a Beckman glucose analyser. The plasma glucose value was entered into a computer algorithm ${ }^{18}$ and the infusion of $20 \%$ dextrose altered accordingly to keep the value constant. The glucose infusion rate reached a steady state by 90 minutes, and the 90-120 minute infusion rate was used as a measure of whole body insulin resistance. The plasma glucose concentration during this period had a coefficient of variation of under $5 \%$. This infusion rate divided by the plasma glucose concentration gives the metabolic clearance rate of glucose $(\mathrm{ml} / \mathrm{kg} / \mathrm{min})$. Blood samples were collected at half hour intervals during the clamp for estimation of electrolyte, insulin, and non-esterified fatty acid values. In addition, plasma insulin concentrations were determined every five minutes from 90 to 120 minutes. Leucocyte efflux and intracellular electrolyte values were measured at rest and at 120 minutes.

\section{LEUCOCYTE STUDIES}

\section{${ }^{22} \mathrm{Na}$ Efflux determinations}

${ }^{22} \mathrm{Na}$ Efflux rate constant determinations were as described. ${ }^{19}$ Briefly, leucocytes were separated from $40 \mathrm{ml}$ blood by dextran sedimentation..$^{20}$ Half of the leucocytes were used for ${ }^{22} \mathrm{Na}$ efflux studies. These leucocytes were loaded with ${ }^{22} \mathrm{Na}$ in TC 199 , specific activity $1110 \mathrm{MBq} / \mathrm{l}$, and after centrifugation the pellet washed once in TC 199. Efflux was measured in TC 199 at $37^{\circ} \mathrm{C}$ with and without ouabain $100 \mu \mathrm{mol} / \mathrm{l}$, aliquots of cell suspension over 30 minutes (unpublished observations); and as all washing was completed within 15 minutes there was minimal loss of intracellular sodium. Furthermore, the extracellular fluid contaminating every pellet was likely to contribute less than $\mathbf{0 . 1 \%}$ of any sodium (and less for potassium) measured finally after the three washes (unpublished observations). Pellets were then weighed to the nearest microgram and dried to constant weight in an oven at $80^{\circ} \mathrm{C}$ for 24 hours. Dry weight is about $25 \%$ of wet weight. Pellets were dissolved in nitric acid $0 \cdot 1 \mathrm{~mol} / 1$, lithium nitrate $15 \mathrm{mmol} / 1$ being used as internal standard. Concentrations of $\mathrm{Na}^{+}$and $\mathrm{K}^{+}$were measured by flame photometry and intracellular electrolytes expressed as $\mathrm{mmol} / \mathrm{kg}$ dry weight. In 13 duplicate determinations a week apart the coefficient of variation was $11 \%$ for $\mathrm{Na}^{+}$and $9 \cdot 2 \%$ for $\mathrm{K}^{+}$. We have found that there is no significant difference in the intracellular concentrations of $\mathrm{Na}^{+}$and $\mathrm{K}^{+}$between polymorphonuclear and mononuclear leucocytes $(n=12)$.

Efflux rates were calculated as the product of the intracellular sodium and efflux rate constant and expressed as $\mathrm{mmol} / \mathrm{kg}$ dry weight $/ \mathrm{h}$.

\section{OTHER ASSAYS}

Insulin concentrations were measured by radioimmunoassay. ${ }^{23}$ Plasma electrolyte values were determined by flame photometry and glucose concentration by the glucose oxidase method on a Beckman analyser. Plasma non-esterified fatty acid determinations were by the acylcoenzyme A synthetase method. ${ }^{24}$ Incremental plasma insulin area and decremental plasma non-esterified fatty acid areas were calculated from the plasma concentration-time curves.

\section{STATISTICS}

As efflux rate constants and electrolyte values showed a Gaussian distribution comparisons were by Student's $t$ test, paired and unpaired as appropriate. Efflux rates, intracellular sodium concentrations, and ouabain sensitive efflux rate constants before and after the meal or euglycaemic clamp were also compared by analysis of variance with repeated measures to determine the contribution of sex and obesity to the changes described. Correlations reported for the meal and insulin clamp studies are Spearman correlation coefficients as numbers were relatively small. Results are expressed as mean and standard deviations (SD), and two tailed $p$ values are quoted.

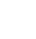




\section{Results}

Obese subjects had significantly higher systolic blood pressures than the normal group (127 (14) $v 117$ (11) $\mathrm{mm} \mathrm{Hg;}<<0.002$ ) but diastolic pressures were similar (obese group 79 (9) $\mathrm{mm} \mathrm{Hg}$, normal group 76 (7) $\mathrm{mm} \mathrm{Hg}$; NS). The table shows the leucocyte intracellular sodium concentrations and ouabain sensitive ${ }^{22} \mathrm{Na}$ efflux rate constants and efflux rates in the normal and obese subjects stratified by sex. Obese subjects had significantly higher ouabain sensitive efflux rate constants than normal subjects, which was true whether men and women were analysed separately or together. Though there was no significant difference in intracellular sodium concentrations between obese and normal subjects, concentrations were higher in women, which may account for the higher ouabain sensitive efflux rate in normal women, as there was no significant difference in the ouabain sensitive efflux rate constant between the sexes. Ouabain insensitive efflux rate constants were significantly higher in normal compared with obese subjects $(0.66$ $(0.25) v 0.53(0.14) / \mathrm{h} ; \mathrm{p}<0.009)$.

Responses to the test meal differed between the two groups. In the 11 normal subjects after two hours there was an increase from the fasting value in the total ${ }^{22} \mathrm{Na}$ efflux rate constant $(3.06(0.44)$ to $3.32(0.47) / \mathrm{h} ; \mathrm{p}<0.003)$ and the ouabain sensitive efflux rate constant $(2.39(0.33)$ to $2.71(0.40) / \mathrm{h}$, $\mathrm{p}<0.0001$; fig 1$)$. The 13 obese subjects did not show any increase from the fasting value (total efflux rate constant $3.22(0.55)$ to $3.26(0.58) / \mathrm{h}$, ouabain sensitive efflux rate constant $2.65(0.54)$ to $2.61(0.58) / \mathrm{h} ;$ fig 1$)$. Intracellular potassium remained unchanged with feeding in both groups. Intracellular sodium concentrations rose from the respective fasting values in both groups (normal group $30 \cdot 7(9 \cdot 9)$ to $38 \cdot 1(9 \cdot 8) \mathrm{mmol} / \mathrm{kg}, \mathrm{p}<0.004$; obese group 25.5 $(6.6)$ to $31.0(6.0) \mathrm{mmol} / \mathrm{kg}, \mathrm{p}<0.008)$. The increase in ouabain sensitive efflux rates was greater $(p<0.02)$ in normal subjects (from 74.2 $(30.1)$ to $102.9(29.5) \mathrm{mmol} / \mathrm{kg} / \mathrm{h} ; \mathrm{p}<0.0001)$ than the obese $(67.7(23.2)$ to 81.5 $(24.6) \mathrm{mmol} / \mathrm{kg} / \mathrm{h} ; \mathrm{p}<0.009$; fig 2). Passive (ouabain insensitive) efflux rates were unchanged from the fasting value in normal subjects $(20.5(8.9)$ to 22.9 $(6.9) \mathrm{mmol} / \mathrm{kg} / \mathrm{h}$; NS) but an increase from the fasting value was found in the obese group $(14 \cdot 6(4 \cdot 8)$ to $20 \cdot 1(7 \cdot 2) \mathrm{mmol} / \mathrm{kg} / \mathrm{h} ; \mathrm{p}<0 \cdot 02)$.

By analysis of variance the rise in ouabain sensitive ${ }^{22} \mathrm{Na}$ efflux rate and efflux rate constant was significantly lower in the obese $(p<0.03$ and $p<0.003$, respectively) with no significant interaction with sex. Overall, women had a higher leucocyte intracellular sodium concentration $(p<0.002)$ but there was no significant contribution from sex to the rise in intracellular sodium with the meal.

Insulin and glucose incremental areas were smaller in normal than obese subjects (insulin area 83.5 (39.0) $v 190.0(110.5) \mathrm{mU} / \mathrm{l} / \mathrm{h}, \mathrm{p}<0.001$; glucose area $0.93(1.82)$ v $2.33(0.94) \mathrm{mmol} / \mathrm{l} / \mathrm{h}, \mathrm{p}<0.03)$. Decremental nonesterified fatty acid areas were similar (normal $0.30(0.18) v$ obese $0.35(0.22)$ $\mathrm{mmol} / \mathrm{l} / \mathrm{h}$ ). The change in leucocyte ouabain sensitive efflux rate constant with feeding was significantly and negatively correlated with body mass index $\left(r_{s}=-0.56 ; p<0.004\right)$ and insulin incremental area $\left(r_{s}=0.53\right.$; $\mathrm{p}<0.008)$.
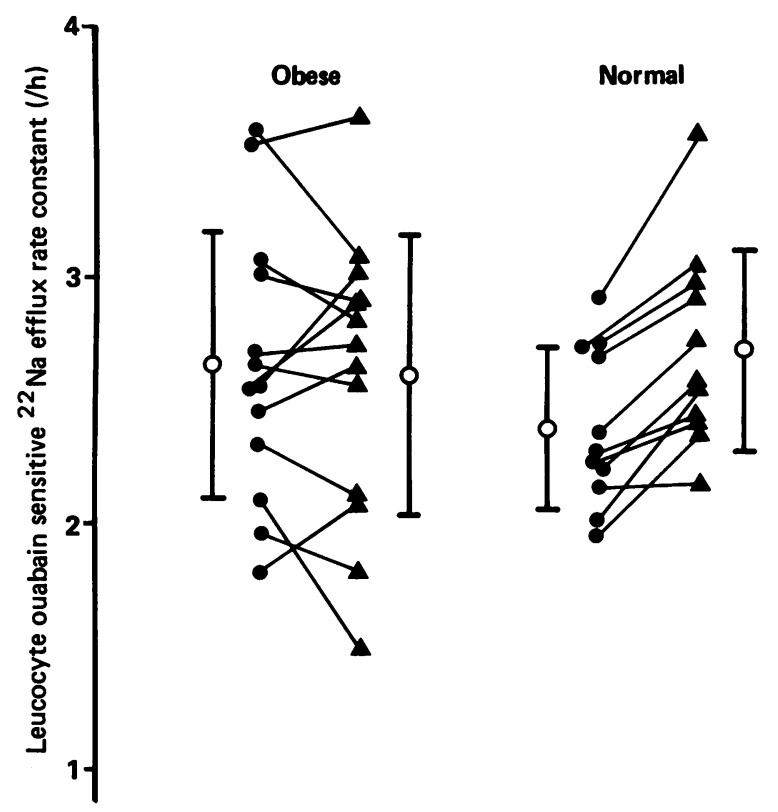

FIG 1-Effect of test meal on leucocyte ${ }^{22} \mathrm{Na}$ ouabain sensitive efflux rate constant in normal and obese subjects. Only rise in ${ }^{22} \mathrm{Na}$ ouabain sensitive efflux rate constant in normal subjects was significant $(p<0 \cdot 0001)$. $=$ Fasting. $\Delta=$ Two hours after meal. $\bigcirc=$ Mean (bars are SD).


Effect of test meal on leucocyte sodium ouabain sensitive efflux rates in normal and obese subjects. Rise in sodium oubain sensitive efflux rates with meal was significant in both normal $(p<0.0001)$ and obese $(p<0.009)$ subjects. $=$ Fasting. $\Delta=$ Two hours after meal. $O=$ Mean (bars are SD).

The hyperinsulinaemic-euglycaemic clamp produced similar plasma insulin concentrations in normal $(69 \cdot 7(8 \cdot 4) \mathrm{mU} / \mathrm{l})$ and obese subjects $(77 \cdot 9$ $(21 \cdot 1) \mathrm{mU} / \mathrm{l})$. A higher metabolic clearance rate of glucose was found in the normal compared with obese subjects $(9 \cdot 86(3 \cdot 27)$ v $3 \cdot 24(1 \cdot 34) \mathrm{ml} / \mathrm{kg} / \mathrm{min}$; $\mathrm{p}<0.0001$ ), reflecting the insulin resistance of obesity. The clamped plasma glucose concentration was slightly lower in the normal than obese subjects $(5.0(0.28) v 5.5(0.58) \mathrm{mmol} / \mathrm{l} ; \mathrm{p}<0.02)$. Plasma non-esterified fatty acid concentrations fell to the same extent in the normal (non-esterified fatty acid area $0.51(0.23) \mathrm{mmol} / / \mathrm{h})$ and obese subjects $(0.46(0.47) \mathrm{mmol} / \mathrm{l} / \mathrm{h})$. In the 10 normal subjects rises from the fasting values in the total and ouabain sensitive efflux rate constants were found after two hours $(3.52(0.54)$ to 3.84 $(0.55) / \mathrm{h}(\mathrm{p}<0.05)$ and $2.74(0.42)$ to $3.16(0.47) / \mathrm{h}(\mathrm{p}<0.004)$, respectively). No such responses were found in the obese group (total efflux rate constant $3.35(0.54)$ to $3.47(0.59) / \mathrm{h}$ (NS); ouabain sensitive efflux rate constant $2.70(0.38)$ to $2.79(0.48) / \mathrm{h}(\mathrm{NS}))$. Intracellular potassium concentrations remained unchanged in both groups, but intracellular sodium rose significantly from fasting values (normal group $32.6(10.0)$ to $39 \cdot 1(11 \cdot 3) \mathrm{mmol} / \mathrm{kg}$ $(p<0.008)$; obese group $27.9(9.3)$ to $32.9(8.5) \mathrm{mmol} / \mathrm{kg}(\mathbf{p}<0.02))$. As a result the change in ouabain sensitive efflux rates was greater $(p<0.05)$ in the normal subjects $(88.8(26.9)$ to $123.8(39.1) \mathrm{mmol} / \mathrm{kg} / \mathrm{h} ; \mathrm{p}<0.002)$ than in the obese subjects $(76.0(28 \cdot 6)$ to $92 \cdot 8(31 \cdot 1) \mathrm{mmol} / \mathrm{kg} / \mathrm{h} ; \mathrm{p}<0.02)$ without significant change in the passive ouabain insensitive efflux rates in either group.

By analysis of variance the change in ouabain sensitive efflux rate constant with the clamp was lower in the obese group $(p<0.03)$. There was no interaction of sex with the change in ouabain sensitive efflux rates or efflux rate constant. The change in ouabain sensitive efflux rates with the clamp, though lower in obese subjects $(p<0.08)$, did not reach conventional levels of significance.

The metabolic clearance rate of glucose during the euglycaemic clamp was highly correlated with the body mass index $\left(r_{s}=0.83 ; p<0.0001\right)$ but not with the change in leucocyte ouabain sensitive or insensitive efflux rates or intracellular sodium concentration. It was significantly correlated with the change in the ouabain sensitive efflux rate constant $\left(r_{s}=0.48 ; p<0.03\right)$. Only in the obese subjects was the metabolic clearance rate of glucose directly related to the intracellular potassium concentration $\left(r_{s}=0.68\right.$; $p<0.03)$, the correlation being non-significant in normal subjects $\left(r_{s}=0.36\right)$.

\section{Discussion}

Reduced sodium pump activity has been found in animal models of obesity..$^{1-3}$ There is controversy over this in human obesity, with reports of reduced, ${ }^{13-15}$ raised, ${ }^{16}$ or unchanged ${ }^{17}$ activity of the sodium pump in erythrocytes. In nucleated human cells there is agreement that sodium pump activity is raised in muscle, ${ }^{25}$ liver, ${ }^{26}$ and leucocytes ${ }^{27}$ in the obese. We have found that the leucocyte ouabain sensitive efflux rate constant is raised and the ouabain insensitive efflux rate constant significantly depressed in obesity. 
This suggests an increased fractional turnover rate of the sodium pump, though the lack of difference in the ouabain sensitive efflux rates implies that changes in intracellular sodium have limited persistence of any differences in efflux rates that may have existed initially. We did not find a lowered intracellular sodium concentration, which may have been because of either $(a)$ the variability in measuring this parameter or $(b)$ an increased influx of sodium over the long term in obesity, which may be related to the hyperinsulinaemia..$^{28}$ We have assumed that the sodium pump of leucocytes reflects the activity of other nucleated cells ${ }^{29}$ and that there is no difference in the efficiency of the process between normal and obese subjects. If so then the lack of difference in the fasting leucocyte ouabain sensitive efflux rates between normal and obese subjects cannot explain the tendency to gain weight in obesity.

We have also found a raised intracellular sodium concentration in women, whether obese or of normal weight. No sex difference in leucocyte sodium values has previously been reported. ${ }^{20}$ This increase in intracellular sodium largely accounted for the raised efflux rate in normal women. The differences in efflux rate constant and intracellular sodium values were not due to differences in the proportion of polymorphonuclear and mononuclear leucocytes as they have similar ouabain sensitive efflux rate constants and amounts of intracellular sodium.

In this initial part of the study the obese subjects were significantly older than the normal controls. Age has been reported to be associated with a lowering of erythrocyte sodium pump activity. ${ }^{30}$ If this is also true for leucocytes then a larger difference in the fractional turnover rate ( ${ }^{22} \mathrm{Na}$ ouabain sensitive efflux rate constant) of the sodium pump might have been detectable in a younger obese population.

Ingestion of protein, carbohydrate, and fat is associated with an increase in energy expenditure-the thermic effect of food. In obesity some workers have found a reduced dietary thermogenesis for mixed meals or glucose, ${ }^{8-11}$ which others have not confirmed. ${ }^{31-37}$ Differences in energy expenditure measuring techniques, the duration of observation after the meal, how the results are expressed, or the size and nature of the energy load may account for these discrepancies. When 24 hour energy expenditure is studied in a respiration chamber a defect in dietary thermogenesis in the obese is detectable. ${ }^{37}$ The thermic effect of food may depend on several processes-for example, the energy cost of storing food, the energy cost of substrate cycles, the increase in sympathetic nervous activity leading to an increase in energy expenditure, and any change in sodium pump rate. The sodium pump may participate in a "futile" cycle, as any sodium entering the cell has to be extruded against a gradient, which is energetically costly. ${ }^{45}$

We have previously shown that ingestion of oral glucose leads to an increase in the leucocyte ${ }^{22} \mathrm{Na}$ ouabain sensitive efflux rate constant in normal but not obese subjects. ${ }^{38}$ In this study there was an increase in the ouabain sensitive efflux rate constant, efflux rates, and intracellular sodium in normal subjects two hours after a meal. This means that there was an increase in sodium influx and that sodium pump activity was also activated. The similarity of this postprandial response to that during the insulin clamp suggests a role for insulin in these processes. Indeed, insulin has been found to increase sodium influx in muscle ${ }^{28}$ and also to stimulate the sodium pump in various tissues. ${ }^{19} 3940$

On the contrary, in the obese, though there was an increase in intracellular sodium, there was no increase in the ouabain sensitive efflux rate constant. The increase in ouabain sensitive efflux rates was smaller than in the normal subjects and was presumably due to the rise in intracellular sodium. Likewise, there was a rise in the passive efflux rate of sodium. Thus there is a failure of the sodium pump to respond as in normal subjects, which may partly account for the defective dietary thermogenesis in obesity. Such a defect in the postprandial activation of cellular sodium pumping may be associated with the insulin resistance of obesity.

We tested the hypothesis that the smaller postprandial rise in sodium pump activity in obesity was associated with insulin resistance by infusing insulin and glucose into normal and obese subjects by the hyperinsulinaemic-euglycaemic clamp technique. Raising insulin acutely in normal subjects led to an increase in intracellular sodium concentrations, ouabain sensitive efflux rate constant, and efflux rates. In obesity the same findings as with the meal were obtained-that is, there was an increase in intracellular sodium but no increase in ouabain sensitive efflux rate constant and therefore a smaller increase in the ouabain sensitive efflux rate of sodium than normal. The thermic effect of insulin and glucose infusions has been shown to be lower in obesity, ${ }^{12}$ which may partly be due to a reduced response in cellular sodium pumping to insulin. The thermic defect is reversible by increasing plasma insulin concentrations ${ }^{41}$ but it is not known whether the defect in activation of cellular sodium pumping in obesity may be so reversed.

Hypertension is more common in obesity and is associated with insulin resistance and hyperinsulinaemia. ${ }^{42}$ If an acute effect of insulin is to increase intracellular sodium in vascular smooth muscle then vascular tone might increase owing to raised intracellular calcium. ${ }^{43}$ As activation of active sodium efflux is less in obesity, the increased intracellular sodium from energy intake or insulin should persist longer, possibly with a deleterious effect on blood pressure in the long term. Energy restriction without salt restriction has a hypotensive effect in obesity. ${ }^{44}$

An additional factor suggested by our insulin clamp studies may be a relation between intracellular potassium and insulin sensitivity in obesity. A significant correlation between the metabolic clearance rate of glucose and intracellular potassium was found in obese but not normal subjects. It is known that both glucose tolerance and insulin secretion are impaired in potassium depletion. ${ }^{45}$ Both glucose tolerance and insulin secretion are improved by potassium supplementation.

In summary we have shown, firstly, that though there may be no difference in the leucocyte sodium pump activity (when expressed as absolute efflux rates) in obesity, increased activity may have been present as the ouabain sensitive efflux rate constant is increased. If sodium pumping contributes substantially to energy expenditure equality accords with a normal resting energy expenditure (when expressed per unit of lean body mass) in obesity, though absolute measures are raised. ${ }^{46}$ Secondly, eating a meal increases cellular sodium pump activity in normal people but less so in obese subjects. The rise in obese subjects is purely due to an increase in intracellular sodium, probably via an increase in sodium influx, which also leads to an increased passive efflux rate. The postprandial responses of the leucocyte sodium pump are reproduced by insulin and glucose infusions.

We put forward the hypothesis that in human obesity a defect in the responses of the cellular sodium pump to feeding or insulin may contribute to any defective dietary thermogenesis. Whether this defect existed before weight gain or results from it is unknown, but in the obese it would produce greater energetic efficiency. Though such a defect in the postprandial activation of the sodium pump is small, it might cumulatively lead to positive energy balance over a long period. The ability of insulin to increase intracellular sodium concentrations may also be the basis of the association between hyperinsulinaemia, hypertension, and obesity.

We thank Mr A D Hutchings, Mrs S Humphreys, Miss E Kinch, and Mrs J McLean-Bushnell for technical help and Mrs V Thursfield for statistical analyses. We are indebted to the Oxford Diabetes Trust for financial support of the Sheikh Rashid Diabetes Unit.

\section{References}

1 Bray GA, York DA, Yukimura Y. Activity of $\left(\mathrm{Na}^{+}+\mathrm{K}^{+}\right)$ATPase in the liver of animals with experimental obesity. Life Sci 1978;22:1637-42.

2 Lin MH, Romsos DR, Akera T, Leveille GA. Na ${ }^{+}, \mathrm{K}^{+}-$ATPase enzyme units in skeletal muscle from lean and obese mice. Biochem Biophys Res Commun 1978;80:398-404.

3 York DA, Bray GA, Yukimura Y. An enzymatic defect in the obese (ob/ob) mouse: loss of thyroid induced sodium and potassium-dependent adenosine triphosphatase. Proc Natl Acad Sci USA 1978;75:477-81.

4 Chinet A, Clausen T, Girardier L. Microcalorimetric determination of energy expenditure due to active sodium-potassium transport in the soleus muscle and brown adipose tissue of the rat. active sodium-potassium
$\mathcal{T}$ Physiol 1977;265:43-61.

5 Ismail-Beigi G, Edelman IS. Mechanism of thyroid calorigenesis: role of active sodium transport. Proc Natl Acad Sci USA 1970;67:1071-8.

6 Swaminathan R, Burrows G, McMurray J. Energy cost of sodium pump activity in man: an in-vivo study of metabolic rate in human subjects given digoxin. IRCS Clin Biochem 1982;10:949.

7 James WPT, Trayhurn P. An integrated view of the metabolic and genetic basis for obesity. Lancet 1976;ii:770-3.

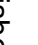
(1) . . . 
8 Shetty PS, Jung RT, James WPT, Barrand MA, Callingham BA. Postprandial thermogenesis in obesity. Clin Sci 1981;60:519-25.

9 Golay A, Schutz Y, Meyer HU, et al. Glucose-induced thermogenesis in nondiabetic and diabetic obese subjects. Diabetes 1982;31:1023-8.

10 Swaminathan R, King RFGJ, Holmfield J, Siwek RA, Baker M, Wales JK. Thermic effect of feeding carbohydrate, fat, protein and mixed meal in lean and obese subjects. Am $\mathcal{f}$ Clin Nutr 1985;42:117-81.

11 Pittet PH, Chappuis K, Acheson F, de Techtermann F, Jequier E. Thermic effect of glucose in obese subjects studied by direct and indirect calorimetry. Brf Nutr 1976;35:281-92.

12 Ravussin E, Bogardus C, Schwartz RS, et al. Thermic effect of infused glucose and insulin in man: decreased response with increased insulin resistance in obesity and noninsulin dependent diabetes mellitus. F Clin Invest 1983;172:893-902.

13 De Luise M, Blackburn GL, Flier JS. Reduced activity of the red-cell sodium-potassium pump in human obesity. $N$ Engl f Med 1980;303:1017-22.

14 Klimes I, Nagulesparan M, Unger RH, Aronoff SL, Mott DM. Reduced $\mathrm{Na}^{+}, \mathrm{K}^{+}$ATPase activity in intact red cells and isolated membranes from obese man. $\mathcal{J}$ Clin Endocrinol Metab 1982;54:721-4.

15 Sowers JR, Whitfield LA, Beck FWJ, et al. Role of enhanced sympathetic nervous system activity and reduced $\mathrm{Na}^{+}, \mathrm{K}^{+}$-dependent adenosine triphosphatase activity in maintenance of elevated blood pressuse in obesity: effects of weight loss. Clin Sci 1982;63(suppl 8):121-4s.

16 Mir MA, Charalambous BM, Morgan K, Evans PJ. Erythrocyte sodium-potassium-ATPase and sodium transport in obesity. $N$ Engl f Med 1981;305:1264-8.

17 Beutler E, Kuhl W, Sacks P. Sodium-potassium-ATPase activity is influenced by ethnic origin and not by obesity. $N$ Engl f Med 1983;309:756-60.

18 Pacini G, Finegood DT, Bergman RN. A minimal-model-based glucose clamp yielding insulin sensitivity independent of glycemia. Diabetes 1982;31:432-41.

$19 \mathrm{Ng} \mathrm{LL}$, Hockaday TDR. The leucocyte sodium pump in healthy and obese subjects: the association of insulin with its activity. Clin Endocrinol 1986;25:383-92.

20 Baron DN, Ahmed SA. Intracellular concentrations of water and of the principal electrolytes determined by analysis of isolated human leucocytes. Clin Sci 1969;37:205-19.

21 Hilton PJ, Patrick J. Sodium and potassium flux rates in normal human leucocytes in an artificia extracellular fluid. Clin Sci 1973;44:439-45.

22 Poston L, Jones RB, Hilton PJ. Sodium transport in polymorphonuclear leucocytes: effect of isolation by the Ficoll/Triosil method. Clin Sci 1982;62:563-4.

23 Morgan CR, Lazarow A. Immunoassay of insulin using a two-antibody system. Proc Soc Exp Biol Med 1962;110:29-32.

24 Shimizu S, Inoue K, Tani Y, Yamada H. Enzymatic microdetermination of serum free fatty acids. Anal Biochem 1979;98:341-5.

25 Charalambous BM, Webster DJT, Mir MA. Elevated skeletal muscle sodium-potassium-ATPase in human obesity. Clin Chim Acta 1984;141:189-95.

26 Bray GA, Kral JG, Bjorntorp P. Hepatic sodium-potassium-dependent ATPase in obesity. NEngl f Med 1981;304:1580-2.

27 Turaihi K, Dandona P, Baron DN. Increased Na-K ATPase in leucocytes of obese patients: effect of weight loss. Clin Sci 1986;70(suppl 13):52P.
28 Rosic NK, Standaert ML, Pollet RJ. The mechanism of insulin stimulation of $\left(\mathrm{Na}^{+}\right.$, $\mathrm{K}^{+}$)-ATPase transport activity in muscle. $\mathcal{F}$ Biol Chem 1985;260:6206-12.

29 Aalkjaer C, Heagerty AM, Parvin SD, Bell PRF, Bing RF, Swales JD. Cell membrane sodium transport: a correlation between human resistance vessels and leucocytes. Lancet 1986; ;:649-51.

30 Naylor GJ, Dick DAT, Warrall EP, Dick EG, Dick P, Boardman L. Changes in erythrocyte sodium pump with age. Gerontology 1977;23:256-61.

31 Nair KS, Halliday D, Garrow JS. Thermic response to isoenergetic protein, carbohydrate and fat meals in lean and obese subjects. Clin Sci 1983;65:307-12.

32 Bradford RB, Jourdan MH. Relative importance of specific dynamic action in weight-reduction diets. Lancet 1973;ii:640-3.

33 Sharief NN, Macdonald I. Differences in dietary-induced thermogenesis with various carbohydrates in normal and overweight man. Am f Clin Nutr 1982;35:267-72.

34 Welle SL, Campbell RG. Normal thermic effect of glucose in obese women. Am $\mathcal{F}$ Clin Nutr 1983;37:87-92.

35 Felig P, Cunningham J, Levitt $M$, Hendler R, Nadel E. Energy expenditure in obesity in fasting and postprandial state. Am $\mathcal{F}$ Physiol 1983;244:E45-51.

36 Nair KS, Webster J, Garrow JS. Effect of impaired glucose tolerance and type II diabetes on resting metabolic rate and thermic response to a glucose meal in obese women. Metabolism 1986;35:640-4

37 Jequier E, Schutz Y. Long term measurements of energy expenditure in humans using a respiration chamber. Am $\mathcal{f}$ Clin Nutr 1983;38:989-98.

$38 \mathrm{Ng} \mathrm{LL}$, Hockaday TDR. The effect of oral glucose on the leucocyte sodium pump in normal and obese subjects. Clin Endocrinol (in press).

39 Clausen T, Kohn PG. The effect of insulin on the transport of sodium and potassium in rat soleus muscle. I Physiol 1977;265: 19-42.

40 Resh MD, Nemenoff RA, Guidotti G. Insulin stimulation of Na-K-ATPase dependent ${ }^{86} \mathrm{Rb}^{+}$ uptake in rat adipocytes. $\mathcal{F}$ Biol Chem 1980;255:10938-45.

41 Ravussin E, Acheson J, Vernet O, Danforth E, Jequier E. Evidence that insulin resistance is responsible for the decreased thermic effect of glucose in human obesity. $\mathcal{J}$ Clin Invest 1985;76:1268-73.

42 Modan M, Halkin H, Almog S, Lusky A, Eshkol A, Shefi M. Hyperinsulinemia-a link between hypertension, obesity and glucose intolerance. $\mathcal{I}$ Clin Invest 1985;75:809-17.

43 Blaustein MP. Sodium ions, calcium ions, blood pressure regulation, and hypertension: a reassessment and a hypothesis. Am f Physiol 1977;232:C165-73.

44 Reisin E, Abel R, Modan M, Silverberg DS, Eliahou HE, Modan B. Effect of weight loss without salt restriction on the reduction of blood pressure in overweight hypertensive patients. $N$ Englf Med 1978;298:1-6.

45 Conn JW. Hypertension, the potassium ion and impaired carbohydrate tolerance. $N$ Engl $\mathrm{F}$ Med 1965;273:1135-42.

46 James WPT, Davies HL, Bailes J, Dauncey MJ. Elevated metabolic rates in obesity. Lancet 1978;i:1122-5.

\begin{abstract}
The concentration of substrate expressed as hypoxanthine capable of reacting with xanthine oxidase to release superoxide free radicals $\left(\mathrm{O}_{2}^{-}\right)$was measured in control and Dupuytren's contracture palmar fascia. In Dupuytren's contracture palmar fascia the concentration of hypoxanthine was six times that of control and was greatest in "nodular" areas. Xanthine oxidase activity was also detected in Dupuytren's contracture palmar fascia.

These results suggest a greater potential for hypoxanthinexanthine oxidase generated oxygen free radical formation in Dupuytren's contracture than in control palmar fascia. Production of free radicals may be an important factor in the pathogenesis of Dupuytren's contracture. The benefit of allopurinol in the management of Dupuytren's contracture and other fibrotic conditions may thus be explained, as allopurinol binds to xanthine oxidase and prevents release of free radicals.

Nuffield Department of Orthopaedic Surgery, University of Oxford, Nuffield Orthopaedic Centre, Oxford OX3 7LD

G A C MURRELL, MB, BS, research fellow

M J O FRANCIS, MA, DPHIL, university lecturer in biochemistry

L BROMLEY, BSC, medical laboratory scientific officer

Correspondence to: Dr Murrell.
\end{abstract}

\section{Introduction}

Dupuytren's contracture affects the palmar fascia, which becomes thickened and shortened and may lead to disabling fixed flexion deformities of the fingers. The prevalence in white populations is between $4 \%$ and $6 \%$, rising to $20 \%$ in men over $65,{ }^{1}$ and is higher in diabetics, particularly when retinopathy is present, but lower in patients with rheumatoid arthritis. ${ }^{23}$

The cause is unknown but may include localised ischaemia of the palmar fascia. ${ }^{45}$ During ischaemia adenosine triphosphate is broken down, increasing the amount of the purine bases hypoxanthine and xanthine and converting xanthine dehydrogenase to xanthine oxidase $^{67}$ (fig 1). Xanthine oxidase, located in the endothelial cells of small vessels, ${ }^{8}$ catalyses the conversion of both hypoxanthine to xanthine and xanthine to uric acid. Both reactions produce superoxide free radicals $\left(\mathrm{O}_{2}^{-}\right)$and hydrogen peroxide $\left(\mathrm{H}_{2} \mathrm{O}_{2}\right)$. Superoxide free radicals, hydrogen peroxide, and their degradation products may damage various tissues and alter vascular permeability. ${ }^{9 \cdot 11}$ In animal studies allopurinol (a competitive inhibitor of xanthine oxidase) and free radical scavengers such as superoxide dismutase and catalase limited the damage associated with acute ischaemia. ${ }^{12}{ }^{13}$ Preliminary clinical results suggest that allopurinol may improve Dupuytren's contracture. ${ }^{14}$

To see whether free radicals might be important in the pathogenesis of Dupuytren's contracture we have measured the concentration of substrates able to react with exogenous xanthine oxidase to produce superoxide free radicals in Dupuytren's and control palmar fascia. These substrates are most likely to 